\title{
EFFECTS OF PRODIGIOSIN 25-C ON CULTURED CELL LINES: ITS SIMILARITY TO MONOVALENT POLYETHER IONOPHORES AND VACUOLAR TYPE $\mathrm{H}^{+}$-ATPase INHIBITORS
}

\author{
TaKaO KataOKa $^{\dagger}$, Junju MagaE ${ }^{a}$, Kunihiro Kasamo ${ }^{b}$, Hiroyasu Yamanishi ${ }^{b}$, \\ AKIRA ENDO ${ }^{c}$, MaKari Yamasaki and KazUo NaGaI ${ }^{a}$ \\ Department of Agricultural Chemistry, The University of Tokyo, \\ 1-1-1 Yayoi, Bunkyo-ku, Tokyo 113, Japan \\ ${ }^{a}$ Department of Bioengineering, Tokyo Institute of Technology, \\ 4259 Nagatsuta-cho, Midori-ku, Yokohama 227, Japan \\ ${ }^{\mathrm{b}}$ Molecular Function Laboratory, National Food Research Institute, \\ 2-1-2 Kannodai, Tsukuba Science City, Ibaraki 305, Japan \\ ${ }^{\mathrm{C}}$ Department of Applied Biological Science, Tokyo Noko University, \\ 3-5-8 Saiwaicho, Fuchu, Tokyo 183, Japan
}

(Received for publication April 13, 1992)

\begin{abstract}
Prodigiosin 25-C inhibited the proliferation of various cultured cell lines more strongly when concanavalin $\mathrm{A}$ (Con $\mathrm{A}$ ) was added to the cultures. The increase in sensitivity was most evident in $\mathrm{T}$ lymphoma YAC-1 cells. The combination of prodigiosin $25-\mathrm{C}$ and $\mathrm{Con} \mathrm{A}$ induced characteristic morphological changes in these cells. In the presence of Con A, monovalent polyether ionophores and vacuolar type $\mathrm{H}^{+}$-ATPase inhibitors induced effects similar to those of prodigiosin 25-C on YAC-1 cells. Prodigiosin 25-C had neither $\mathrm{K}^{+}$ionophore activity nor inhibitory effect on vacuolar type $\mathrm{H}^{+}$-ATPase. A Golgi mannosidase II inhibitor, swainsonine, inhibited the proliferation of YAC-1 cells only when Con A was added. Prodigiosin $25-\mathrm{C}$ and swainsonine increased Con A binding receptors on the surface of $\mathrm{YAC}-1$ cells. These results suggest that prodigiosin $25-\mathrm{C}$ affects the intracellular transport and/or processing of glycoproteins.
\end{abstract}

Prodigiosin $25-\mathrm{C}$ is an immunosuppressant that inhibits the proliferation of $\mathrm{T}$ cells induced by the plant lectins, Con A and phytohemagglutinin, more strongly than the proliferation of B cells induced by lipopolysaccharide ${ }^{1)}$. In a mixed lymphocyte reaction, prodigiosin $25-\mathrm{C}$ suppressed cytotoxic $\mathrm{T}$ lymphocytes induction ${ }^{1,2)}$. When prodigiosin $25-\mathrm{C}$ was administered to mice, the compound completely suppressed cytotoxic $\mathrm{T}$ lymphocytes induction, but antibody production was unaffected ${ }^{2,3)}$. These results indicate that prodigiosin 25-C inhibits cytotoxic $\mathrm{T}$ lymphocytes induction without affecting the in vivo functions of helper $\mathrm{T}$ cells and $\mathrm{B}$ cells.

The mitogen response of murine splenocytes was inhibited more strongly by prodigiosin $25-\mathrm{C}$ when the cells were stimulated with higher concentration of Con $\mathrm{A}^{3)}$. In both $\mathrm{T}$ cells and $\mathrm{B}$ cells purified from murine splenocytes, the inhibitory effect of prodigiosin 25-C was enhanced by the addition of Con $\mathrm{A}^{4}$. The increased sensitivity was also observed in the lectins which bind to mannose residues of biantennary-complex-type sugar chains ${ }^{4)}$. These results suggested that the inhibitory effect of prodigiosin 25-C was closely related to the expression and the structure of cell surface glycoproteins. In this paper, we further examined the effects of prodigiosin $25-\mathrm{C}$ on cultured cell lines.

+ Present Address: Department of Bioengineering, Tokyo Institute of Technology, 4259 Nagatsuta-cho, Midori-ku, Yokohama 227, Japan 


\section{Materials and Methods}

Cells

T lymphoma YAC-1 cell, T lymphoma EL-4, thymoma L5178-Y, B lymphoma A20.2J, mastcytoma P815 and macrophage cell line J774A.1 were maintained in RPMI1640 medium supplemented with 10\% (v/v) fetal calf serum (GIBCO Laboratories, Gland Island, U.S.A.), $50 \mu \mathrm{M}$ 2-mercaptoethanol, $50 \mu \mathrm{g} / \mathrm{ml}$ kanamycin and $8 \mu \mathrm{g} / \mathrm{ml}$ tylosin tartrate. T cell line CTLL-2, helper T cell line HT-2 and natural killer cell line SPB2.45) were maintained in the presence of human recombinant IL-2. Myeloid cell line FDC.P2 was maintained in the presence of WEHI-3 supernatant.

\section{Proliferation Assay}

Cells $(1,000$ or 5,000 cells $/$ well, $0.1 \mathrm{ml})$ were incubated with inhibitors at $37^{\circ} \mathrm{C}$ for 48 or 72 hours in a microtiter plate. After being pulse-labeled with $\left[{ }^{3} \mathrm{H}\right]$ thymidine $(0.5 \mu \mathrm{Ci} /$ well $)$ for 4 hours, cells were harvested and the radioactivity of them was measured in a liquid scintillation counter.

\section{Measurement of Ionophore Activity ${ }^{6}$}

A half $\mathrm{ml}$ of aqueous buffer $(25 \mathrm{~mm}$ Tris- $\mathrm{HCl}, \mathrm{pH} 8.5)$ containing radioactive potassium ion $\left({ }^{42} \mathrm{~K}\right)$ and $0.5 \mathrm{ml}$ of $30 \% n$-buthanol $-70 \%$ toluene mixture $(\mathrm{v} / \mathrm{v})$ containing an antibiotic were mixed vigorously and the radioactivities of both phases were measured in a gamma counter.

\section{Measurement of $\mathrm{H}^{+}$-ATPase Activity}

Plant vacuole from malt was prepared by the method of MATSUURA-ENDo et al. ${ }^{7)}$. Vacuolar membrane was incubated in $30 \mathrm{~mm}$ MES-Tris ( $\mathrm{pH} 7.5$ ), $50 \mathrm{~mm} \mathrm{KCl,} 3 \mathrm{~mm} \mathrm{MgSO}_{4}, 3 \mathrm{~mm} \mathrm{ATP}, 50 \mathrm{~mm}$ ammonium molybdate and $1 \mu \mathrm{M}$ gramicidin $\mathrm{D}$ at $38^{\circ} \mathrm{C}$ for 30 minutes at a final volume of $0.5 \mathrm{ml}$. The reaction was terminated by the addition of $0.1 \mathrm{ml}$ of $50 \%(\mathrm{w} / \mathrm{v})$ trichloroacetic acid and the amount of free phosphate was measured.

\section{Con A Binding Assay}

YAC-1 cells $\left(5 \times 10^{6}\right.$ cells $\left./ \mathrm{ml}, 0.2 \mathrm{ml}\right)$ were incubated with $\left[{ }^{3} \mathrm{H}\right] \mathrm{Con}$ A $(8.5 \mu \mathrm{Ci} / \mathrm{mmol}$, Amersham International plc, Buckinghamshire, England) in HANKs' balanced salt solution containing $2 \%(\mathrm{v} / \mathrm{v})$ fetal calf serum and $0.02 \%(\mathrm{w} / \mathrm{v})$ sodium azide at $37^{\circ} \mathrm{C}$ for 40 minutes. Cell suspension was overlaid onto $80 \%$ di- $n$-butyl phthalate $-20 \%$ olive oil $(\mathrm{v} / \mathrm{v})$ and centrifuged $(2,000 \times g, 2$ minutes). The cell pellet was dissolved in $0.3 \mathrm{ml}$ of $10 \%(\mathrm{w} / \mathrm{v})$ Triton $\mathrm{X}-100$ and the radioactivity was measured in ten volumes of Aquasol-2 (New England Nuclear, Boston, U.S.A.). To distinguish nonspecific binding from specific binding, YAC-1 cells were incubated with $\left[{ }^{3} \mathrm{H}\right] \mathrm{Con} A$ in the presence of $100 \mathrm{~mm} \alpha$-methyl-D-mannoside.

\section{Chemicals}

Prodigiosin 25-C, bafilomycin $\mathrm{B}_{1}$ and ML-236B were prepared in our laboratories. Brefeldin $\mathrm{A}$ and tunicamycin were the gifts from A. TAKATSUKI. Concanamycin A was provided by Taisho Pharmaceutical Co., Ltd., Tokyo. Other reagents including Con A, antibiotics and inhibitors were purchased from Sigma Chemicals Co., St. Louis, U.S.A.

\section{Results}

Ten cultured cell lines were incubated with prodigiosin $25-\mathrm{C}$ in the presence or absence of Con $\mathrm{A}$ for 72 hours (Table 1). $\mathrm{ID}_{50}$ values of prodigiosin $25-\mathrm{C}$ on these cell lines ranged from $3.2 \mathrm{ng} / \mathrm{ml}$ to $35 \mathrm{ng} / \mathrm{ml}$, but there was no correlation between the origin of cell lines and the sensitivity to prodigiosin 25-C. By the addition of Con $\mathrm{A}$, the sensitivity to prodigiosin $25-\mathrm{C}$ was increased in all of these cell lines tested in Table 1, but the degree of the enhancement varied from 1.3-fold in J774A.1 cells to 60-fold in YAC-1 cells. The sensitivities to prodigiosin 25-C in CTLL-2, J774A.1, P815, FDC.P2 and SPB2.4 increased by only about 2-fold, whereas HT-2, L5178-Y, EL-4 and A20.2J were sensitive to more than 5-fold as low as prodigiosin 
Table 1. Effect of prodigiosin 25-C on the proliferation of various cultured cell lines in the presence of Con A.

\begin{tabular}{|c|c|c|c|c|}
\hline \multirow{2}{*}{ Cell lines } & \multicolumn{2}{|c|}{$\left[{ }^{3} \mathrm{H}\right]$ Thymidine incorporation $(\mathrm{cpm})$} & \multicolumn{2}{|c|}{$\mathrm{ID}_{50}(\mathrm{ng} / \mathrm{ml})$} \\
\hline & None & Con A & None & Con A \\
\hline CTLL-2 & $23,252 \pm 2,149$ & $2 \mathrm{I}, 670 \pm 1,238$ & 3.2 & 1.5 \\
\hline HT-2 & $89,919 \pm 7,970$ & $77,634 \pm 3,896$ & 16.0 & 2.7 \\
\hline YAC-1 & $54,137 \pm 4,650$ & $35,001 \pm 2,581$ & 12.0 & 0.2 \\
\hline L5178-Y & $127,008 \pm 1,643$ & $114,293 \pm 4,080$ & 15.5 & 1.5 \\
\hline EL4 & $89,029 \pm 6,758$ & $65,518 \pm 2,490$ & 11.5 & 2.2 \\
\hline $\mathrm{A} 20.2 \mathrm{~J}$ & $42,365 \pm 2,022$ & $27,538 \pm 2,328$ & 35.0 & 4.2 \\
\hline J774A. 1 & $84,413 \pm 4,201$ & $86,387 \pm 3,102$ & 21.0 & 16.0 \\
\hline P815 & $105,200 \pm 3,713$ & $81,610 \pm 3,112$ & 6.0 & 2.7 \\
\hline FDC.P2 & $96,373 \pm 2,613$ & $87,459 \pm 2,888$ & 18.0 & 10.5 \\
\hline SPB2.4 & $26,285 \pm 332$ & $23,523 \pm 3,447$ & 27.0 & 11.5 \\
\hline
\end{tabular}

Cells $(1,000$ cells/well, $0.1 \mathrm{ml})$ were incubated with prodigiosin $25-\mathrm{C}$ in the presence or absence of Con A $5 \mu \mathrm{g} / \mathrm{ml}$ for 72 hours. Mean \pm SD cpm of $\left[{ }^{3} \mathrm{H}\right]$ thymidine incorporation in triplicate cultures and $\mathrm{ID}_{50}$ values of prodigiosin $25-\mathrm{C}$ on them were presented.

Table 2. Effect of various inhibitors on the proliferation of YAC-1 cells in the presence of Con A.

\begin{tabular}{|c|c|c|c|c|c|c|c|}
\hline \multirow{2}{*}{$\begin{array}{l}\text { Compounds } \\
\text { (concentration) }\end{array}$} & \multicolumn{2}{|c|}{$\mathrm{ID}_{50}$} & \multirow{2}{*}{$\begin{array}{c}\text { Ratio } \\
\text { (None/ } \\
\text { Con A) }\end{array}$} & \multirow{2}{*}{$\begin{array}{l}\text { Compounds } \\
\text { (concentration) }\end{array}$} & \multicolumn{2}{|c|}{$\mathrm{ID}_{50}$} & \multirow{2}{*}{$\begin{array}{l}\text { Ratio } \\
\text { (None/ } \\
\text { Con A) }\end{array}$} \\
\hline & None & Con $\mathrm{A}$ & & & None & Con A & \\
\hline Mitomycin C (ng/ml) & 3.0 & 2.4 & 1.3 & Prodigiosin $25-\mathrm{C}(\mathrm{ng} / \mathrm{ml})$ & 18 & 0.62 & 29 \\
\hline Actinomycin $\mathrm{D}(\mathrm{ng} / \mathrm{ml})$ & 0.44 & 0.52 & 0.85 & Nigericin $(\mathrm{ng} / \mathrm{ml})$ & 54 & 15 & 3.6 \\
\hline Cycloheximide $(\mathrm{ng} / \mathrm{ml})$ & 9.4 & 7.2 & 1.3 & Nonactin (ng/ml) & 19 & 24 & 0.79 \\
\hline Cerulenin $(\mu \mathrm{g} / \mathrm{ml})$ & 1.8 & 1.3 & 1.4 & Valinomycin $(\mathrm{ng} / \mathrm{ml})$ & 1.6 & 3.1 & 0.52 \\
\hline $\mathrm{ML}-236 \mathrm{~B}(\mu \mathrm{M})$ & 4.5 & 30 & 0.15 & $\mathrm{~A} 23187(\mu \mathrm{M})$ & 0.32 & 0.27 & 1.2 \\
\hline Amphotericin B $(\mu \mathrm{g} / \mathrm{ml})$ & 1.5 & 1.6 & 0.90 & Bafilomycin $B_{1}$ (ng/ml) & 1.9 & 0.44 & 4.3 \\
\hline Antimycin A $(\mathrm{ng} / \mathrm{ml})$ & 2.8 & 2.4 & 1.2 & Concanamycin A $(\mathrm{ng} / \mathrm{ml})$ & 0.43 & 0.12 & 3.6 \\
\hline Gramicidin $\mathrm{S}(\mathrm{ng} / \mathrm{ml})$ & 11 & 11 & 1.0 & Oligomycin $(\mathrm{ng} / \mathrm{ml})$ & 4.3 & 4.3 & 1.0 \\
\hline Cytochalasin $\mathrm{D}(\mu \mathrm{g} / \mathrm{ml})$ & 1.3 & 1.0 & 1.3 & Ouabain $(\mu \mathrm{g} / \mathrm{ml})$ & 58 & 52 & 1.1 \\
\hline Vincristine $(\mathrm{ng} / \mathrm{ml})$ & 4.4 & 4.9 & 0.90 & Chloroquine $(\mu \mathrm{g} / \mathrm{ml})$ & 5.0 & 3.9 & 1.3 \\
\hline Brefeldin $\mathrm{A}(\mu \mathrm{g} / \mathrm{ml})$ & 0.26 & 0.23 & 1.1 & Methylamine $(\%)$ & 0.032 & 0.016 & 2.0 \\
\hline Tunicamycin (ng/ml) & 4.5 & 3.6 & 1.3 & Swainsonine $(\mu \mathrm{g} / \mathrm{ml})$ & $>10$ & 0.078 & $>128$ \\
\hline Monensin $(\mathrm{ng} / \mathrm{ml})$ & 52 & 9.4 & 5.5 & & & & \\
\hline
\end{tabular}

YAC-1 cells $(5,000$ cells/well, $0.1 \mathrm{ml})$ were incubated with prodigiosin $25-\mathrm{C}$ in the presence or absence of Con $\mathrm{A}$ $5 \mu \mathrm{g} / \mathrm{ml}$ for 48 hours in triplicate cultures. ID $_{50}$ values of various inhibitors on them and ID $_{50}$ ratio were presented.

25-C in the presence of Con A. The increase of sensitivity of T lymphoma YAC-1 cells was most evident, and the cells were used for the following experiments.

The primary target of prodigiosin $25-\mathrm{C}$ is still unknown and the increased sensitivity in the presence of Con A was not observed with other immunomodulators such as FK506 and cyclosporin $\mathrm{A}^{3 \text { k }}$. Inhibitors which have different mechanisms of action were examined to determine whether they become more effective when combined with Con A (Table 2). Among the inhibitors tested in Table 2, monovalent polyether ionophores, monensin and nigericin, a vacuolar type $\mathrm{H}^{+}$-ATPase inhibitor bafilomycin $\mathrm{B}_{1}{ }^{83}$, its structurally related compound concanamycin $\mathrm{A}^{9)}$ and a Golgi mannosidase II inhibitor swainsonine ${ }^{10)}$ significantly inhibited the proliferation of YAC-1 cells in the presence of Con A. It should be noted that swainsonine had no inhibitory effect on YAC-1 cells by itself at $10 \mu \mathrm{g} / \mathrm{ml}$. None of the other types of ionophores including $\mathrm{A} 23187$, nonactin and valinomycin, $\mathrm{Na}^{+} / \mathrm{K}^{+}$-ATPase inhibitor ouabain, and $\mathrm{F}_{1} \mathrm{~F}_{0}$-ATPase 
Fig. 1. Inhibitory effect of Con A on the proliferation of YAC-1 cells in the presence of various inhibitors.

$\circ$ None, $\square$ monensin $20 \mathrm{ng} / \mathrm{ml}$, $\mathbf{n}$ nigericin $10 \mathrm{ng} / \mathrm{ml}, \Delta$ bafilomycin $\mathrm{B}_{1} 1 \mathrm{ng} / \mathrm{ml}, \Delta$ concanamycin $\mathrm{A}$ $0.3 \mathrm{ng} / \mathrm{ml}$, swainsonine $1 \mu \mathrm{g} / \mathrm{ml}, \nabla$ prodigiosin $25-\mathrm{C} 10 \mathrm{ng} / \mathrm{ml}$.

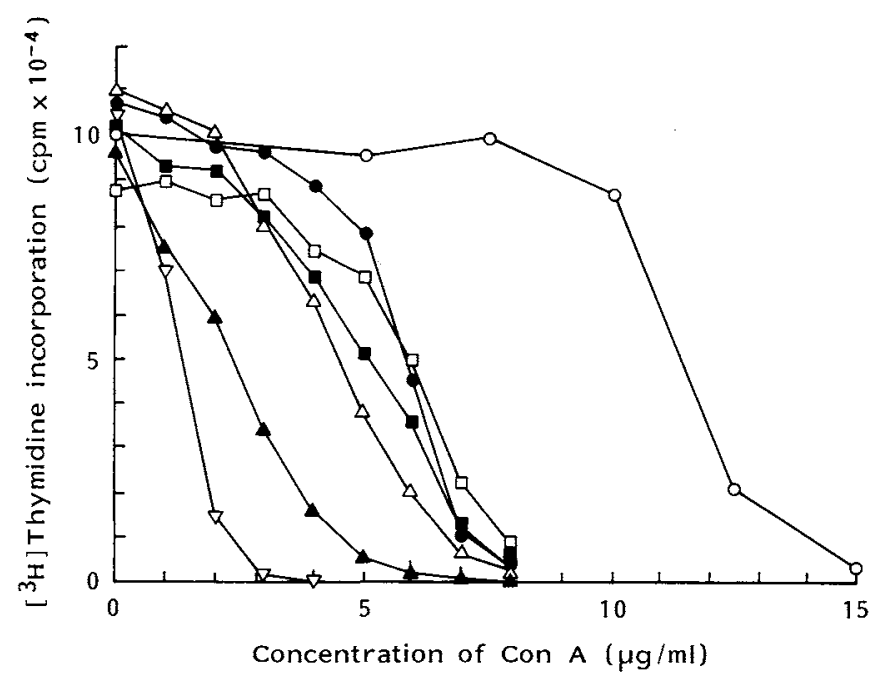

YAC-1 cells $(5,000$ cells $/ \mathrm{ml}, 0.1 \mathrm{ml})$ were incubated with Con A in the presence of various inhibitors for 48 hours in triplicate cultures.

inhibitor oligomycin showed such effect. On the contrary, YAC-1 cells were rendered more resistant to ML-236B ${ }^{11)}$ by the addition of Con A. Preliminary experiments showed that Con A inhibited the incorporation of exogenous cholesterol (data not shown). These findings suggest that $\mathrm{HMG}$ - CoA reductase, a target enzyme of ML-236B, increases in the presence of Con A and YAC-1 cells consequently become resistant to the drug.

The ID $_{50}$ value of Con A on YAC-1 cells decreased from 11.5 to $6 \mu \mathrm{g} / \mathrm{ml}$ in the presence of swainsonine, whereas it decreased to $1.5 \mu \mathrm{g} / \mathrm{ml}$ following the addition of prodigiosin 25-C (Fig. 1). Polyether ionophores, monensin and nigericin and vacuolar type $\mathrm{H}^{+}$-ATPase inhibitor bafilomycin $\mathrm{B}_{1}$ also increased the sensitivity of the cells to Con A by about 2-fold, but a 4.6-fold increase was observed in the case of concanamycin A (Fig. 1).

Con $\mathrm{A}$ induced the agglutination of YAC-1 cells without affecting the cell shapes (Fig. 2B and 2C) and $10 \mathrm{ng} / \mathrm{ml}$ of prodigiosin 25-C did not change their shape (Fig. 2D). But, with the combination of prodigiosin 25-C and Con A, elongated cells and enlarged cells appeared (Fig. 2J). Similar morphological changes were induced by monensin (Fig. 2K), nigericin (Fig. 2L), bafilomycin $B_{1}$ (Fig. 1M) and concanamycin A (Fig. $2 \mathrm{~N}$ ) only in the presence of Con A. In contrast, swainsonine and Con A induced merely enlarged cells (Fig. 2O). Thus, the effect of prodigiosin 25-C was similar to that of polyether ionophores and vacuolar type $\mathrm{H}^{+}$-ATPase inhibitors rather than that of swainsonine.

Ionophore activity against potassium ions was measured using a two phase distribution system (Table 3). Nigericin efficiently transported ${ }^{42} \mathrm{~K}$ from an aqueous phase to an organic phase. In the case of valinomycin, small but significant radioactivity was detected in an organic phase. Valinomycin had only a little ionophore activity as compared with nigericin, probably because the dissociation constant for the interaction of potassium ions with valinomycin is much larger than that with nigericin ${ }^{12}$. Prodigiosin $25-\mathrm{C}$ showed no ionophore activity against potassium ion under these experimental conditions. 
Fig. 2. Morphological changes of YAC-1 cells.

(A)

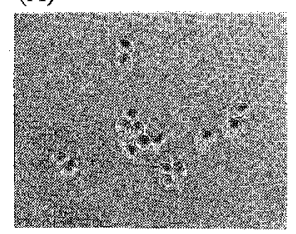

(D)

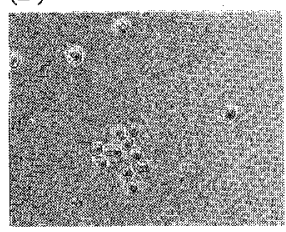

(G)

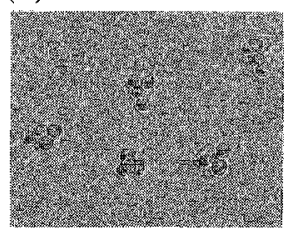

(J)

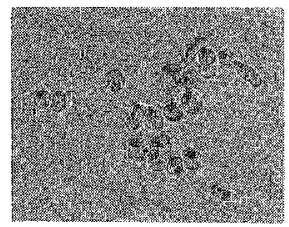

(M)

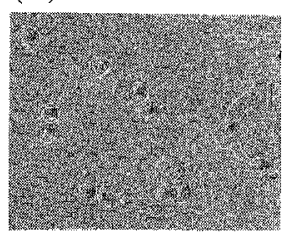

(B)

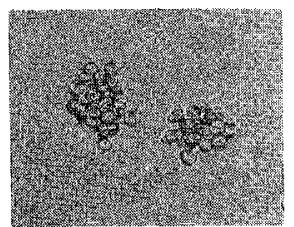

(E)

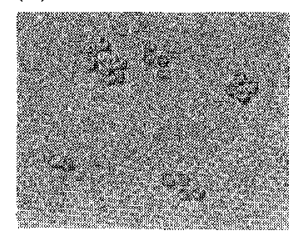

(H)

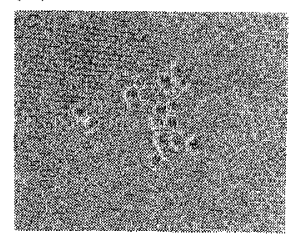

(K)

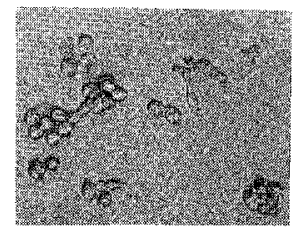

(N)

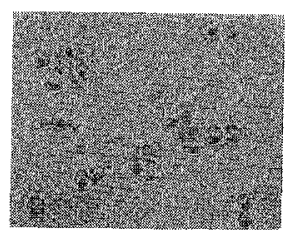

(C)

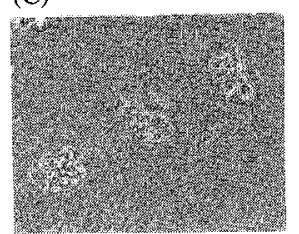

(F)

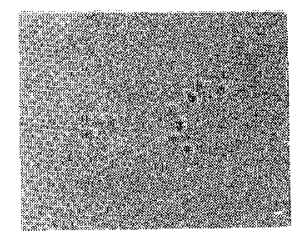

(I)

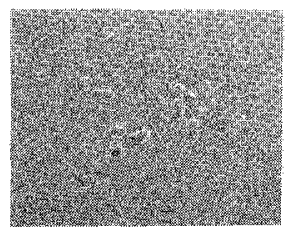

(L)

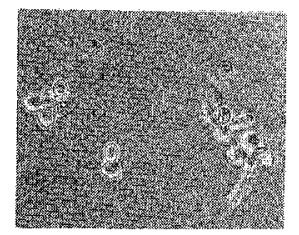

(O)

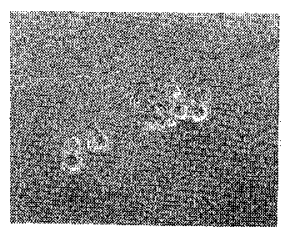

YAC-1 cells were incubated with various inhibitors in the presence or absence of Con A for 24 hours. A: control, B: Con A $5 \mu \mathrm{g} / \mathrm{ml}$, C: Con A $7.5 \mu \mathrm{g} / \mathrm{ml}$, D: prodigiosin $25-\mathrm{C} 10 \mathrm{ng} / \mathrm{ml}$, E: monensin $20 \mathrm{ng} / \mathrm{ml}$, F: nigericin $20 \mathrm{ng} / \mathrm{ml}, \mathrm{G}$ : bafilomycin $\mathrm{B}_{1} 1 \mathrm{ng} / \mathrm{ml}, \mathrm{H}$ : concanamycin A $1 \mathrm{ng} / \mathrm{ml}$, I: swainsonine $1 \mu \mathrm{g} / \mathrm{ml}, \mathrm{J}$ : prodigiosin $25-\mathrm{C} 10 \mathrm{ng} / \mathrm{ml}$ plus Con A $5 \mu \mathrm{g} / \mathrm{ml}, \mathrm{K}:$ monensin $20 \mathrm{ng} / \mathrm{ml}$ plus Con A $5 \mu \mathrm{g} / \mathrm{ml}$, L: nigericin $20 \mathrm{ng} / \mathrm{ml}$ plus Con A $5 \mu \mathrm{g} / \mathrm{ml}$, M: bafilomycin $\mathrm{B}_{1} 1 \mathrm{ng} / \mathrm{ml}$ plus Con A $5 \mu \mathrm{g} / \mathrm{ml}$, N: concanamycin A $1 \mathrm{ng} / \mathrm{ml}$ plus Con A $5 \mu \mathrm{g} / \mathrm{ml}$, O: swainsonine $1 \mu \mathrm{g} / \mathrm{ml}$ plus Con A $7.5 \mu \mathrm{g} / \mathrm{ml}$.

The activity of plant vacuolar type $\mathrm{H}^{+}$-ATPase was calculated by assaying the amount of free phosphate produced through hydrolysis of ATP (Table 4). $\mathrm{HNO}_{3}$ and bafilomycin $\mathrm{B}_{1}$, known inhibitors of the enzyme, significantly inhibited the activity. Concanamycin A also inhibited ATPase activity almost completely, suggesting that concanamycin $\mathrm{A}$ is an inhibitor of vacuolar type $\mathrm{H}^{+}$-ATPase similar to bafilomycin $\mathrm{B}_{1}$. However, prodigiosin 25-C had only a small effect at $20 \mu \mathrm{g} / \mathrm{ml}$.

YAC-1 cells were incubated with prodigiosin $25-\mathrm{C}$ or swainsonine for 72 hours and the amount of Con A binding receptors on cell surface were estimated (Fig. 3). Prodigiosin 25-C and swainsonine increased Con A binding receptors to about twice the control level. 
Table 3. Ionophore activity against potassium ion.

\begin{tabular}{lcc}
\hline \multirow{2}{*}{ Compounds } & \multicolumn{2}{c}{ Radioactivity of ${ }^{\mathbf{4 2}} \mathrm{K}(\mathrm{cpm})$} \\
\cline { 2 - 3 } & $\begin{array}{c}\text { Toluene/buthanol } \\
\text { phase }\end{array}$ & Aqueous phase \\
\hline None & 11 & 1,208 \\
Nigericin & 609 & 567 \\
Valinomycin & 58 & 1,102 \\
Prodigiosin 25-C & 9 & 1,141 \\
\hline
\end{tabular}

Table 4. Plant vacuolar type $\mathrm{H}^{+}$-ATPase activity.

\begin{tabular}{lcr}
\hline \multicolumn{1}{c}{ Treatment } & $\begin{array}{r}\text { Specific activity } \\
(\mu \mathrm{mol} / \mathrm{min} / \mathrm{mg})\end{array}$ & $\begin{array}{r}\mathrm{T} / \mathrm{C} \\
(\%)\end{array}$ \\
\hline Control & 0.464 & 100 \\
Vanadate $(50 \mu \mathrm{M})$ & 0.396 & 85 \\
$\mathrm{HNO}_{3}(50 \mathrm{~mm})$ & 0.058 & 12 \\
${\text { Bafilomycin } \mathrm{B}_{1}(2 \mu \mathrm{g} / \mathrm{ml})}_{\text {Concanamycin } \mathrm{A}(2 \mu \mathrm{g} / \mathrm{ml})}$ & 0.027 & 6 \\
Monensin $(2 \mu \mathrm{g} / \mathrm{ml})$ & 0.015 & 3 \\
Prodigiosin $25-\mathrm{C}(20 \mu \mathrm{g} / \mathrm{ml})$ & 0.387 & 83 \\
\hline
\end{tabular}

Fig. 3. Effect of prodigiosin 25-C on the expression of Con A binding receptors on YAC-1 cells.

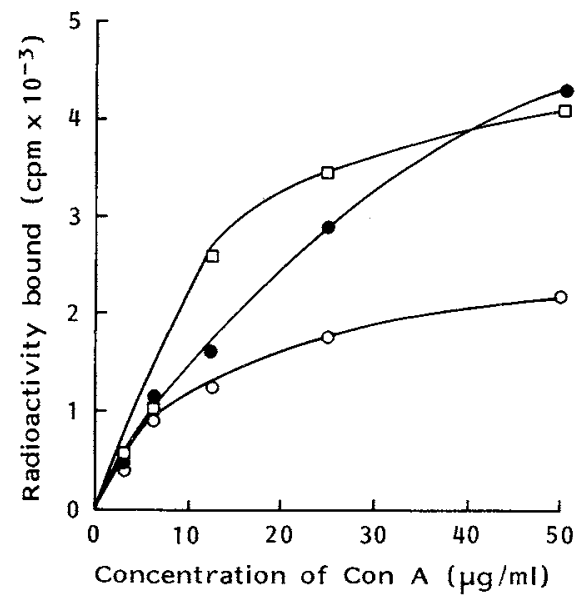

YAC-1 cells were incubated with prodigiosin $25-\mathrm{C}$ $10 \mathrm{ng} / \mathrm{ml}$ (closed circle), swainsonine $1 \mu \mathrm{g} / \mathrm{mol}$ (open square) or no addition (open circle) for 72 hours and the amount of Con $\mathrm{A}$ binding receptors was measured.

\section{Discussion}

Prodigiosin 25-C was found as an immunosuppressant which inhibited the proliferation of $\mathrm{T}$ cells more strongly than that of $\mathrm{B}$ cells ${ }^{11}$. When Con $\mathrm{A}$ was added to the culture, the inhibitory effect of prodigiosin $25-\mathrm{C}$ was markedly enhanced in splenic $\mathrm{B}$ cells as well as in splenic $\mathrm{T}$ cells $\mathrm{s}^{3,4)}$. The increased sensitivity was also observed in several cultured cell lines including lymphoid and myeloid cells, and was most evident in T lymphoma YAC-1 cells.

We found that monovalent polyether ionophores, vacuolar type $\mathrm{H}^{+}$-ATPase inhibitors and Golgi mannosidase II inhibitor inhibited the proliferation of YAC-1 cells more strongly in the presence of Con A as did prodigiosin 25-C. Swainsonine inhibited the proliferation of YAC-1 cells only when Con A was added to their culture. Prodigiosin 25-C and Con A induced characteristic morphological changes on YAC-1 cells such as the appearance of enlarged cells and elongated cells but these changes were not observed in other cell lines listed in Table 1. Monovalent polyether ionophores and vacuolar type $\mathrm{H}^{+}$-ATPase inhibitors also induced similar morphological changes, whereas swainsonine induced only the appearance of enlarged cells. These results suggest that the effect of prodigiosin $25-\mathrm{C}$ resembles that of monovalent polyether ionophores and vacuolar type $\mathrm{H}^{+}$-ATPase inhibitors rather than that of swainsonine. However, prodigiosin 25-C had no ionophore activity against potassium ion in a two phase distribution system. Since the structure of prodigiosin $25-\mathrm{C}$ differs from that of all known ionophores, which contain several oxygen atoms to complex the ions, it is unlikely that prodigiosin $25-\mathrm{C}$ has ionophore activity against cations.

In this paper, we showed that concanamycin $A$, which is structurally related to bafilomycin $B_{1}$, inhibited plant vacuolar type $\mathrm{H}^{+}$-ATPase. However, prodigiosin $25-\mathrm{C}$ had no inhibitory effect on plant vacuolar type $\mathrm{H}^{+}$-ATPase. Vacuolar type $\mathrm{H}^{+}$-ATPase generates an internal acidic environment in the intracellular organella such as endosome, lysosome and Golgi apparatus ${ }^{13)}$. We have recently found that bafilomycin $\mathrm{B}_{1}{ }^{14)}$ and concanamycins ${ }^{15,16)}$ are potent inhibitors of ATP-dependent acidification of endosomes and lysosomes in mammalian cells. Monovalent polyether ionophores can transport not only cations but also protons across the lipid bilayer and monensin is known to perturb the structure and function of the Golgi apparatus by raising the vacuolar $\mathrm{pH}$, resulting in the inhibition of glycoprotein transport ${ }^{17,18}$. Again, the increased sensitivity and the morphological changes with Con A in YAC-1 cells 
were observed with only monovalent polyether ionophores, but not with A23187, nonactin and valinomycin, which are inert to transport proton across membrane. Thus, these results suggest that prodigiosin 25-C affects vacuolar acidification especially in the Golgi apparatus.

Asparagine-linked sugar chains of glycoproteins are divided into three groups termed highmannose-type, hybrid-type and complex-type. Con A binds to biantennary-complex-type, high-mannosetype and hybrid-type sugar chains ${ }^{19,20)}$. Swainsonine converts complex-type into hybrid-type sugar chains and increases cell surface expression of Con $\mathrm{A}$ binding receptors ${ }^{21}$. Prodigiosin $25-\mathrm{C}$ also increased Con A binding receptors in YAC-1 cells by about 2-fold as did swainsonine. Since swainsonine itself was not toxic to cultured cell lines and increased the sensitivity to Con A of YAC-1 cells by 2-fold, YAC-1 cells may be preferentially killed by the toxic effect of Con A in the presence of swainsonine. Prodigiosin 25-C induced on YAC-1 cells a 7.7-fold increase of sensitivity to Con A, which was much greater than that expected from the 2-fold increase of Con A binding receptors and elongated morphology in the presence of Con A unlike swainsonine. These results suggest that both swainsonine and prodigiosin 25-C cause increase of the number of Con A binding receptors on $\mathrm{YAC}-1$ cells, but prodigiosin 25-C had some additional effect involved in the synergistic effect with Con A.

Taken together the results presented in this paper suggest that prodigiosin $25-\mathrm{C}$ affects the intracellular transport and processing of glycoproteins and change their expression and structure through raising vacuolar $\mathrm{pH}$. We are now carrying out some biochemical experiments including the isolation of the prodigiosin $25-\mathrm{C}$ binding protein, which will make an important clue to address the mode of action of prodigiosin $25-\mathrm{C}$ on the molecular level. The mechanism of vacuolar acidification will be elucidated by studying the mode of action of prodigiosin $25-\mathrm{C}$.

\section{Acknowledgment}

We thank M. SCHAECHTER for the help in the preparation of this manuscript. This work was supported by the Grant-in-Aid for the "Biodesign Research Program" from RIKEN to K. NAGAI and a Cancer Research Grant from the Ministry of Education, Science and Culture of Japan.

\section{References}

1) Nakamura, A.; K. Nagai, K. Ando \& G. Tamura: Selective suppression by prodigiosin of the mitogenic response of murine splenocytes. J. Antibiotics 39: 1155 1159, 1986

2) Nakamura, A.; J. Magae, R. F. Tsuji, M. Yamasaki \& K. Nagai: Suppression of cytotoxic T cell induction in vivo by prodigiosin 25-C. Transplantation 47: 1013 1016, 1989

3) Tsuji, R. F.; M. Yamamoto, A. Nakamura, T. Kataoka, J. Magae, K. Nagai \& M. Yamasaki: Selective immunosuppression of prodigiosin 25-C and FK 506 in the murine immune system. J. Antibiotics 43: 1293 1301, 1990

4) Kataoka, T.; J. Magae, H. Nariuchi, M. Yamasaki \& K. Nagai: Enhancement by concanavalin A of the suppressive effect of prodigiosin 25-C on proliferation of murine splenocytes. J. Antibiotics 45: 1303 1312, 1992

5) Hattori, M.; T. Sudo, M. Iizuka, S. Kobayashi, S. Nishio, S. Kano \& N. Minato: Generation of continuous large granular lymphocyte lines by interleukin 2 from the spleen cells of mice infected with moloney leukemia virus. Involvement of interleukin 3. J. Exp. Med. 166: 833 849, 1987

6) Mitani, M.; T. Yamanishi \& Y. Miyazaki: Salinomycin: A new monovalent caticn ionophore. Biochem. Biophys. Res. Comm. 66: $1231 \sim 1236,1975$

7) Matsuura-Endo, C.; M. Maeshima \& S. Yoshida: Subunit composition of vacuolar membrane $\mathrm{H}^{+}-\mathrm{ATPase}_{\text {from }}$ mung bean. Eur. J. Biochem. 187: 745 751, 1990

8) Bowman, E. J.; A. Siebers \& K. Altendorf: Bafilomycins: A class of inhibitors of membrane ATPases from microorganisms, animal cells, and plant cells. Proc. Natl. Acad Sci. U.S.A. 85: 7972 7976, 1988

9) Kinashi, H.; K. Someno \& K. SaKaguchi: Isolation and characterization of concanamycins A, B and C. J Antibiotics 37: 1333 1343, 1984

10) Tulsiani, D. R. P.; T. M. Harris \& O. Touster: Swainsonine inhibits the biosynthesis of complex glycoproteins by inhibition of golgi mannosidase II. I. Biol. Chem. 257: 7936 7939, 1982

11) ENDo, A. \& K. Hasumi: Biochemical aspect of HMG CoA reductase inhibitors. In Advances in Enzyme Regulation. Vol. 28. Ed., G. Weber, pp. 53 64, Pergamon Press, 1989

12) Pressman, B. C.: Biological applications of ionophores. Annu. Rev. Biochem. 45: 501 530, 1976 
13) Mellman, I.; R. Fuchs \& A. Helenius: Acidification of the endocytic and exocytic pathways. Annu. Rev. Biochem. 55: $663 \sim 700,1986$

14) Naganuma, S.; N. Kuzuya, K. Sakal, K. Hasumi \& A. Endo: Inhibition of the accumulation of lipid droplets in macrophage $J 774$ by bafilomycin $B_{1}$ and destruxin E. Biochim. Biophys. Acta. 1126: $41 \sim 48,1992$

15) Woo, J.-T.; C. Shinohara, K. Sakai, K. Hasumi \& A. Endo: Inhibition of the acidification of endosomes and lysosomes by the antibiotics concanamycin B in macrophage J774. Eur. J. Biochem. 207: 383 389, 1992

16) Woo, J.-T.; C. Shinohara, K. Sakai, K. Hasumi \& A. Endo: Isolation, characterization and biological activities of concanamycins as inhibitors of lysosomal acidification. J. Antibiotics 45: 1108 1116, 1992

17) Tartakoff, A. M.: Perturbation of the structure and function of the golgi complex by monovalent carboxylic ionophores. Methods Enzymol. 98: 47 .59, 1983

18) Tartakoff, A. M.: Perturbation of vesicular traffic with the carboxylic ionophore monensin. Cell 32: 1026 1028, 1983

19) Osawa, T. \& T. TsujI: Fractionation and structural assessment of oligosaccharides and glycopeptides by use of immobilized lectins. Annu. Rev. Biochem. 56:21 42, 1987

20) Cummings, R. D.; R. K. Merkle \& N. L. Stults: Separation and analysis of glycoprotein oligosaccharides. Methods Cell Biol. 32: $141 \sim 183,1989$

21) Elberin, A. D.; Y. T. PAN, R. SOLF \& K. VOSBECK: Effect of swainsonine, an inhibitor of glycoprotein processing, on cultured mammalian cells. J. Cell. Physiol. 115: 265 275, 1983 